Jurnal Ekonomika Indonesia Volume X Nomor 2 September 2020

$P$-ISSN : 2338-4123 E-ISSN : 2614-7270

URL: http://ojs.unimal.ac.id/index.php/ekonomika

\title{
DETERMINASI DANA SYIRKAH TEMPORER TERHADAP BAGI HASIL PADA PT. BANK BRI SYARIAH
}

\author{
Nur Aisyah $^{* a}$, Munardi ${ }^{* b}$ \\ * Fakultas Ekonomi dan Bisnis Universitas Malikussaleh \\ a Corresponding author: aisahicha0794@gmail.com \\ b
}

ARTICLE INFORMATION

Keywords: Temporary Syirkah

Funds and Profit Sharing Rate.

\section{A B S T R A C T}

This study aims to determine the effect of temporary Syirkah funds on profit-sharing rates at PT. Bank BRI Syariah. This study uses secondary data in the form of quarterly financial statements for 20122018 accessed on www.bi.go.id and www.brisyariah.co.id. The data analysis method used is a simple linear regression method with the help of Eviews. The results of the study partially show that temporary Syirkah funds significantly influence profit-sharing rates at PT. BRI Syariah Bank.

Keywords: Temporary Syirkah Funds and Profit Sharing Rate.

\section{PENDAHULUAN \\ Latar Belakang Masalah}

Sistem ekonomi syariah atau biasa disebut dengan Ekonomi Islam, semakin populer bukan hanya di negara-negara Islam tapi bahkan juga di negara-negara barat. Banyak kalangan melihat, islam dengan sistem nilai dan tatanan normatifnya sebagai faktor penghambat pembangunan. (S. M. Antonio, 2001)

Adanya Bank Syariah merupakan solusi alternative terhadap persoalan pertentangan antara bunga dan bank dengan riba Perkembangan masyarakat yang semakin sadar akan Islam sebagai agama yang mengatur kehidupan masyarakat secara komprehensif dan universal, berpengaruh juga pada sektor perbankan. Perbankan syariah mulai berkembang pesat diberbagai Negara. (Muhammad Syafi'i Antonio, 2003a)

Berikut ini merupakan Tabel 1 Data Dana Syirkah Temporer dan Bagi Hasil Kepada Nasabah pada PT. Bank BRISyariah dari tahun 2012 sampai tahun 2016.
Tabel 1

Dana Syirkah Temporer dan Bagi Hasil Kepada Nasabah

\begin{tabular}{|c|c|c|c|c|}
\hline \multirow[b]{2}{*}{ Tahun } & \multirow{2}{*}{$\begin{array}{l}\text { Dana Syirkah } \\
\text { Temporer } \\
\text { (Jutaan }\end{array}$} & \multirow[b]{2}{*}{ Rasio } & \multicolumn{2}{|l|}{ Bagi Hasil } \\
\hline & & & $\begin{array}{l}\text { Nasabah } \\
\text { (Miliar Rupiah) }\end{array}$ & Rasio \\
\hline 2012 & Rp. 9.588.611 & & Rp. 527.595 & \\
\hline 2013 & Rp. 11.198.271 & $16,78 \%$ & Rp. 764.590 & $44,91 \%$ \\
\hline 2014 & Rp. 13.026 .816 & $16,32 \%$ & Rp. 994.824 & $30,11 \%$ \\
\hline 2015 & Rp. 15.468 .898 & $18,74 \%$ & Rp. 1.027.442 & $3,24 \%$ \\
\hline 2016 & Rp. 16.712.746 & $8,04 \%$ & Rp. 1.035.502 & $0,78 \%$ \\
\hline Jumlah & Rp. 65.995.342 & & Rp. 4.349.953 & \\
\hline
\end{tabular}

Sumber: Laporan Keuangan BRI Syariah, Tahun 2019

Dari Tabel 1 di atas dapat dilihat bahwa Dana Syirkah Temporer dan Bagi Hasil Kepada Nasabah pada PT. Bank BRI Syariah dari tahun 2012 sampai tahun 2016. Total Dana Syirkah Temporer dari tahun 2012 sampai dengan tahun 2016 yaitu sebesar Rp. 65.995.342 jutaan rupiah. Rasio dana syirkah temporer tertinggi terjadi diantara tahun 2014 dan 2015 yaitu sebesar $18,74 \%$ dan rasio dana syirkah temporer terendah terjadi diantara tahun 2015 dan 2016 yaitu sebesar $8,04 \%$. Sedangkan pada total Tingkat Bagi Hasil Kepada Nasabah pada PT. Bank BRISyariah dari tahun 2012 sampai tahun 2016 yaitu sebesar Rp. 4.349.953 miliar rupiah. Rasio tingkat bagi hasil kepada nasabah tertinggi terjadi 
diantara tahun 2012 dan 2013 yaitu sebesar $44,91 \%$ dan rasio tingkat bagi hasil kepada nasabah terendah terjadi diantara tahun 2015 dan 2016 yaitu sebesar $0,78 \%$.

Berikut ini merupakan tabel 2 Data Dana Syirkah Temporer dan Bagi Hasil Kepada Bank pada PT. Bank BRISyariah dari tahun 2012 sampai tahun 2016.

Tabel 2

Dana Syirkah Temporer dan Bagi Hasil Kepada Bank

\begin{tabular}{|c|c|c|c|c|}
\hline \multirow[b]{2}{*}{ Tahun } & \multirow{2}{*}{$\begin{array}{l}\text { Dana Syirkah } \\
\text { Temporer } \\
\text { (Jutaan } \\
\text { Rupiah) }\end{array}$} & \multirow{2}{*}{ Rasio } & \multicolumn{2}{|c|}{ Bagi Hasil } \\
\hline & & & $\begin{array}{l}\text { Bank (Miliar } \\
\text { Rupiah) }\end{array}$ & Rasio \\
\hline 2012 & Rp. 9.588.611 & & Rp. 810.806 & \\
\hline 2013 & Rp. 11.198.271 & $16,78 \%$ & Rp. 972.921 & $19,99 \%$ \\
\hline 2014 & Rp. 13.026 .816 & $16,32 \%$ & Rp. 1.061.778 & $9,13 \%$ \\
\hline 2015 & Rp. 15.468 .898 & $18,74 \%$ & Rp. 1.397.310 & $31,60 \%$ \\
\hline 2016 & Rp. 16.712 .746 & $8,04 \%$ & Rp. 1.598 .700 & $14,41 \%$ \\
\hline Jumlah & Rp. 65.995 .342 & & Rp. 5.841.515 & \\
\hline
\end{tabular}

Sumber: Laporan Keuangan BRI Syariah, Tahun 2019

Dari Tabel 2 di atas dapat dilihat bahwa Dana Syirkah Temporer dan Bagi Hasil Kepada Bank pada PT. Bank BRI Syariah dari tahun 2012 sampai tahun 2016. Total Dana Syirkah Temporer dari tahun 2012 sampai dengan tahun 2016 yaitu sebesar Rp. 65.995.342 jutaan rupiah. Rasio dana syirkah temporer tertinggi terjadi diantara tahun 2014 dan 2015 yaitu sebesar 18,74\% dan rasio dana syirkah temporer terendah terjadi diantara tahun 2015 dan 2016 yaitu sebesar 8,04\%.

Sedangkan pada total Tingkat Bagi Hasil Kepada Bank pada PT. Bank BRI Syariah dari tahun 2012 sampai tahun 2016 yaitu sebesar Rp. 5.841 .515 miliar rupiah. Rasio tingkat bagi hasil kepada nasabah tertinggi terjadi diantara tahun 2014 dan 2015 yaitu sebesar 31,60\% dan rasio tingkat bagi hasil kepada bank terendah terjadi diantara tahun 2013 dan 2014 yaitu sebesar 9,13\%.

Dari kedua tabel di atas dapat kita ketahui bahwa rasio dari dana syirkah temporer, bagi hasil kepada pihak nasabah dan bagi hasil kepada pihak bank mengalami kenaikan dan penurunan. Namun pertumbuhan dana syirkah temporer jika tidak diiringi dengan penyaluran dan manajemen dana yang baik dapat menjadikan pertumbuhan tersebut tidak cukup berarti bagi perbankan syariah tersebut. Bahkan dapat menjadikan keadaan keuangan memprihatinkan karena banyaknya dana mengendap, distribusi bagi hasil simpanan terus dilakukan dari pendapatan yang dihasilkan setiap bulan, sedangkan penyaluran pembiayaan yang dilakukan masih kurang efektif.

Maka menjadi sebuah pertanyaan besar akan kemampuan sebuah perbankan syariah dalam memaksimalkan potensi dana syirkah temporernya untuk mengembangkan pendapatan perbankan syariah tersebut. Efektifitas penyaluran pembiayaan yang dilakukan dimana hasil pembiayaan akan menjadi pendapatan yang akan mempengaruhi tingkat ekuitas dan perkembangan perbankan syariah secara menyeluruh dari segi keuangannya.

Penelitian ini bertujuan untuk mengetahui dan menganalisis seberapa besar Dana Syirkah Temporer berpengaruh terhadap Bagi Hasil PT. Bank BRISyariah.

Selanjutnya bagian kedua dari penelitian ini akan membahas tinjauan teoritis, metode penelitian akan dibahas pada bagian ketiga. Kemudian pada bagian ke empat akan dibahas hasil penelitian dan pembahasan. Pada bagian kelima akan membahas kesimpulan dan saran.

\section{TINJAUAN TEORITIS \\ Perbankan Syariah}

Bank Syariah adalah bank yang beroperasi dengan tidak mengandalkan pada bunga (Muhammad, 2008).

Bank Islam (Islamic Bank) adalah bank yang pengoperasiannya disesuaikan dengan prinsip syariat Islam (Wardiah, 2013).

Bank Syariah adalah lembaga yang berfungsi sebagai intermediasi yaitu mengerahkan dana dari masyarakat dan menyalurkan kembali dana-dana tersebut kepada masyarakat yang membutuhkan dalam bentuk pembiayaan tanpa berdasarkan prinsip bunga, melainkan berdasarkan prinsip syariah (Shajdeiny, 2007)

\section{Prinsip-prinsip Perbankan Syariah}

Dalam operasinya, bank Syariah mengikuti aturan-aturan dan norma- norma Islam, yaitu biasa disebut anti MAGHRIB (maysir, gharar, riba, dan bathil) (Muhammad Syafi'i Antonio, 2003b). 
Dalam menjalankan usahanya bank syariah dituntut untuk mampu bertahan ditengah persaingan perbankan. Hal ini memicu bank syariah untuk lebih berinovasi dalam menciptkan sebuah produk yang dapat menarik nasabah untuk menannamkan dananya di bank syariah (Kasmir, 2002).

\section{Syirkah}

Syirkah merupakan semua bentuk usaha yang melibatkan dua pihak atau lebih dimana mereka secara bersama-sama memadukan seluruh bentuk sumber daya baik yang berwujud maupun tidak berwujud (Karim, 2006).

\section{Hubungan Dana Syirkah Temporer Dengan Bagi Hasil}

Hubungan antara dana syirkah temporer dengan bagi hasil yaitu apabila Semakin besar dana syirkah temporer yang dihimpun dari pihak ketiga maka tingkat bagi hasil akan semakin tinggi dikarenakan akan semakin besar dana yang dikelola dalam menghasilkan keuntungan. jikaterjadi kerugian normal, entitas syariah tidak wajibmengganti kerugian tersebut (Lukman, 2014).

\section{Kerangka Konseptual}

Kerangka konseptual yang di gunakan untuk memperjelas apakah terdapat Pengaruh Dana Syirkah Temporer Terhadap Bagi Hasil PT. Bank BRI Syariah.

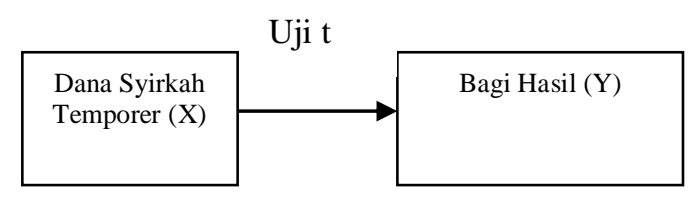

\section{Gambar 1}

\section{Kerangka konseptual}

Gambar 1 menunjukkan dalam penelitian ini, penulis ingin mengetahui pengaruh Dana Syirkah Temporer Terhadap Bagi Hasil PT. Bank BRISyariah. Untuk mengetahui pengaruh dari variabel independent (bebas) terhadap variabel dependent (terikat). Maka yang digunakan adalah uji t. Uji t merupakan pengujian secara parsial variabel Dana Syirkah Temporer (X) Terhadap Bagi Hasil (Y) PT. Bank BRISyariah.

\section{Hipotesis}

H0 : Diduga Dana Syirkah Temporer tidak

berpengaruh terhadap bagi hasil PT. Bank BRI Syariah.

Ha : Diduga Dana Syirkah Temporer berpengaruh terhadap bagi hasil PT. Bank BRI Syariah

\section{METODE PENELITIAN}

\section{Data dan Sumber Data}

Objek dalam penelitian ini adalah PT. Bank BRISyariah dengan melihat pengaruh dari variabel Dana Syirkah Temporer terhadap Bagi Hasil PT. Bank BRISyariah. Lokasi dalam penelitian ini adalah PT. Bank BRISyariah di Indonesia yang berpusat di Jakarta.

Data yang digunakan berdasarkan data yang terdapat di situs Bank BRISyariah, yang diambil melalui website resmi (https://www.brisyariah.co.id) dalam kurun waktu 7 tahun, dari tahun 2012 sampai dengan tahun 2018.

\section{Definisi Operasional Variabel}

Berdasrkan rumusan hipotesis penelitian, variabel penelitian terdiri dari dua variabel. Variabel $X$ sebagai variabel bebas dan Variabel Y sebagai variabelterikat.

\section{Variabel Terikat}

$\mathrm{Y}=$ bagi hasil PT. Bank BRISyariah

Bagi hasil merupakan sistem dimana dilakukan perjanjian atau ikrar bersama dalam melakukan kegiatan usaha. Bagi hasil dalam sistem perbankan syariah merupakan ciri khusus yang ditawarkan kepada masyarakat dan ditentukan dalam aktivitas syariah. Nilai bagi hasil diperoleh dari laporan keuangan PT. Bank BRISyariah secara triwulan dari tahun 2012-2017. Dinyatakan dalam rupiah (Rp).

\section{Variabel Bebas}

$\mathrm{X}=$ Dana Syirkah Temporer

Dana syirkah temporer adalah dana yang diterima oleh Bank dimana Bank mempunyai hak untuk mengelola dan menginvestasikan dana, baik sesuai dengan kebijakan Bank atau kebijakan pembatasan dari pemilik dana, dengan keuntungan dibagikan sesuai dengan kesepakatan. diperoleh dari laporan keuangan PT. Bank BRISyariah 
secara triwulan dari tahun 2012-2017. Dinyatakan dalam rupiah $(\mathrm{Rp})$.

\section{Metode Analisis Data}

Metode regresi yang digunakan untuk mengasumsikan bahwa terdapat hubungan linier antara variabel bagi hasil (Y) dengan variabel Dana Syirkah Temporer (X). Dengan menggunakan Eviews. Adapun model persamaan regresi yang dapat diperoleh dalam analisis ini adalah:

$\mathrm{Y}=\mathrm{a}+\mathrm{bX}+\mathrm{e}$

Dimana:

$\mathrm{Y}=$ Bagi Hasil Bank BRISyariah

$\mathrm{a}=$ Konstanta

$\mathrm{X}=$ Dana Syirkah Temporer

ei $\quad=$ Error Term

Pada dasarnya analisis regresi adalah untuk memperoleh persamaan regresi dengan cara memasukkan perubah satu demi satu sehingga diketahui pengaruh yang paling kuat sampai dengan yang paling lemah.

\section{HASIL PENELITIAN DAN PEMBAHASAN}

Analisis Dana Syirkah Temporer (DST) PT. Bank BRISyariah

Dana syirkah temporer adalah investasi yang diterima oleh Bank. Dana syirkah temporer terdiri dari tabungan mudharabah dan deposito mudharabah. Dalam penelitian ini digunakan data Dana Syirkah Temporer PT. Bank BRISyariah selama 7 tahun yaitu dari tahun 2012 sampai dengan tahun 2018 yang akan diolah seacara triwulan yaitu sebagai berikut:

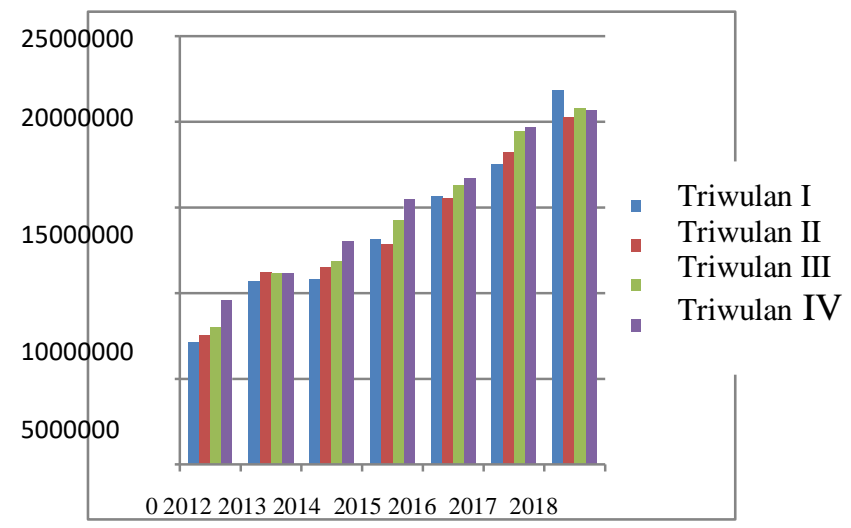

Sumber: Data Diolah (2019)

\section{Gambar 2}

Kurva Dana Syirkah Temporer (dalam Jutaan Rupiah)
Dari Gambar 2 pada kurva di atas dapat diketahui bahwa Dana Syirkah Temporer (DST) dari tahun 2012 sampai dengan tahun 2018 mengalami kenaikan dan penurunan setiap tahunnya. Dana Syirkah Temporer tertinggi terjadi pada triwulan ke I tahun 2018 yaitu sebesar Rp 21.853.979 jutaan rupiah. Sedangkan Dana Syirkah Temporer terendah terjadi pada triwulan ke I tahun 2012 yaitu sebesar Rp 7.127.267 jutaan rupiah.

\section{Analisis Bagi Hasil PT. Bank BRISyariah}

Dalam penelitian ini digunakan data Bagi Hasil PT. Bank BRISyariah selama 7 tahun yaitu dari tahun 2012 sampai dengan tahun 2018 yang akan diolah seacara triwulan yaitu sebagai berikut:

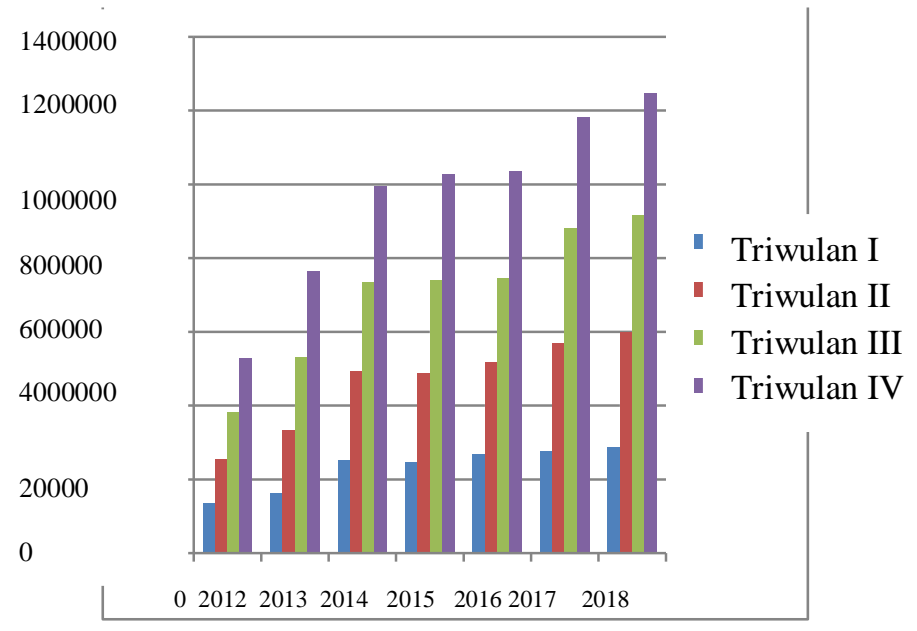

Sumber: Data Diolah (2019)

Gambar 3

\section{Kurva Bagi hasil atas Dana Syirkah Temporer} (dalam Jutaan Rupiah)

Dari Gambar 3 pada kurva di atas dapat diketahui bahwa Bagi Hasil atas Dana Syirkah Temporer dari tahun 2012 sampai dengan tahun 2018 mengalami kenaikan serta penurunan. Bagi hasil atas Dana Syirkah Temporer tertinggi terjadi pada triwulan IV tahun 2018 yaitu sebesar Rp 1.247.462 jutaan rupiah. Sedangkan bagi hasil atas Dana Syirkah Temporer terendah terjadi pada triwulan I tahun 2012 yaitu sebesar Rp 135.794 jutaan rupiah.

\section{Uji Asumsi Klasik \\ Uji Normalitas}

Uji normalitas untuk menguji apakah dalam model regresi, variabel pengganggu atau residual memiliki distribusi normal atau tidak 
dapat diketahui dengan membandingkan nilai Jarque-Bera dengan nilai Chi tabel. Jika nilai Jarque Bera < dari nilai Chi tabel, maka data dalam penelitian berdistribusi normal. (Winarno, 2007).

\section{Tabel 3}

Hasil Uji Normalitas

\begin{tabular}{|l|l|}
\hline Nilai & Jarque- \\
\hline 0.657336 & 37.65248 \\
\hline
\end{tabular}

Sumber: Hasil Olah Data, 2019

Dari Tabel 3 di atas dapat dilihat bahwa $0.657336<37.65248$. Nilai Jarque-Bera sebesar 0.657336 atau berada dibawah nilai X2 tabel yaitu sebesar 37.65248 maka H0 diterima. Kesimpulannya, dapat dikatakan bahwa data terdistribusi normal.

\section{Uji Autokorelasi}

Uji dilakukan dengan menggunakan program Eviews. Menurut (Aisyah, 2015) Durbin dan Watson juga telah menetapkan kaidah keputusan sebagai berikut:

1. $0<\mathrm{dw}<\mathrm{dL}$ Terjadi masalah autokorelasi yang positif yang perlu perbaikan.

2. $\mathrm{dL}<\mathrm{dw}<4$-du Ada autokorelasi yang positif tetapi lemah, dimana perbaikan akan lebih baik.

3. $d u<d w<4-d u$ Tidak ada masalah autokorelasi.

4. 4-du $<\mathrm{dw}<4-\mathrm{dL}$ Masalah autokorelasi lemah, dimana dengan perbaikan akan lebih baik.

5. 4- $\mathrm{dL}<\mathrm{dw}$ Masalah autokorelasi serius.

\section{Tabel 4}

\section{Hasil Uji Autokorelasi}

\begin{tabular}{|l|l|l|l|}
\hline Nilai & Nilai dL & Nilai du & Nilai 4-du \\
\hline 2,46 & 1,32 & 1,47 & 2,53 \\
\hline
\end{tabular}

Sumber: Hasil Olah Data, 2019

Dari Tabel 4 di atas dapat dilihat bahwa nilai $\mathrm{dL}$ dan nilai du dilihat melalui tabel $\mathrm{dw}$ dengan tingkat signifikansi 0,05 . Jumlah $\mathrm{n}=28$ dan jumlah variabel bebas 1 maka didapatkan nilai tabel $\mathrm{dL}=1,32$ nilai $\mathrm{du}=1,47$ nila 4 -du $=2,53$. Dari hasil diatas diperoleh nilai $\mathrm{dw}=2,46$ berada diatas du dan dibawah 4-du maka dapat diambil kesimpulan bahwa tidak ada autokorelasi dalam penelitian ini.

\section{Pembahasan \\ Hasil Estimasi Pengaruh Variabel Bebas Terhadap Variabel Terikat}

\section{Tabel 5}

\section{Hasil Pengolahan Data}

Dependent Variable: Y Method: Least Squares

Date: 01/03/20 Time: 21:55

Sample: 2012Q1 2018Q4

Included observations: 28

\begin{tabular}{|c|c|c|c|}
\hline Variable & Coefficien & $\begin{array}{l}\text { Std. Error } \\
\text { Statistic }\end{array}$ & t-Prob. \\
\hline $\mathrm{C}$ & 41100.53 & $\begin{array}{l}187999.0 \\
0.218621\end{array}$ & 0.8287 \\
\hline $\mathrm{X}$ & 0.038349 & $\begin{array}{l}0.012546 \\
3.056630\end{array}$ & 0.0051 \\
\hline R-squared & 0.264352 & Mean dependent var & 592286.9 \\
\hline $\begin{array}{l}\text { Adjusted } \\
\text { squared }\end{array}$ & R-0.236058 & S.D. dependent var & 321867.9 \\
\hline S.E. of regression & 281324.8 & Akaike info criterion & 28.00116 \\
\hline Sum squared resid & d $2.06 \mathrm{E}+12$ & Schwarz criterion & 28.09631 \\
\hline Log likelihood & -390.0162 & Hannan-Quinn criter. & 28.03025 \\
\hline F-statistic & 9.342985 & Durbin-Watson stat & 2.112701 \\
\hline $\operatorname{Prob}($ F-statistic) & 0.005127 & & \\
\hline
\end{tabular}

Sumber: Hasil Olah Data, 2019

Berdasarkan hasil pengolahan data dari tabel 5 di atas maka dapat dibentuk suatu persamaan regresi adalah sebagai berikut:

$$
\mathrm{Y}=41100.53+0.038349 \mathrm{X}
$$

Dari formula model diatas maka nilai konstanta mempunyai regresi sebesar 41100.53 menunjukkan apabila variabel Dana Syirkah Temporer bernilai 0 (konstan), maka Bagi Hasil atas Dana Syirkah Temporer akan meningkat sebesar 41100.53. Sementara koefisien variabel Dana Syirkah Temporer b=0.038349 menunjukan angka positif yang artinya bahwa setiap kenaikan Dana Syirkah Temporer sebesar Rp 1 rupiah, maka Bagi Hasil atas Dana Syirkah Temporer juga akan meningkat sebesar Rp 0.038349 rupiah. 


\section{Koefisien Korelasi (r) dan Koefisien Determinasi (R2)}

Koefisien korelasi (r) sebesar 0.5141 atau $51.41 \%$ yang merupakan hasil dari akar koefisien determinasi sebesar 0.2643 atau $26.43 \%$. koefisien korerasi sebesar 0.5141 atau $51.41 \%$ artinya bahwa variabel bebas (independent variable) variabel Dana Syirkah Temporer mempunyai hubungan yang erat dengan variabel terikat dalam hal ini adalahbagi hasil atas Dana Syirkah Temporer.

Koefisien determinasi (R2) sebesar 0.2643 atau $26.43 \%$ ini mencerminkan bahwa variabel terikat dapat dijelaskan oleh variabel bebas atau dengan kata lain bahwa kemampuan variabel bebas yang dijelaskan oleh variabel terikat yaitu sebesar $26.43 \%$. sedangkan sisanya sebesar 0.7357 atau $73.57 \%$ di pengaruhi oleh variabel lain yang tidak di teliti dalam penelitian ini.

\section{Uji Signifikansi Parsial (Uji t)}

Uji $\mathrm{t}$ ini digunakan untuk melihat besar pengaruh variabel independen $X$ (Dana Syirkah Temporer) terhadap variabel terikat Y (Bagi Hasil atas Dana Syirkah Temporer) secara parsial pada PT. Bank BRISyariah.

Tabel 6

\section{Hasil Uji t}

\begin{tabular}{|l|c|c|c|l|l|}
\hline & \multicolumn{3}{|c|}{ Variabel Dependen Bagi Hasil atas Dana Syirkah } \\
Temporer \\
\hline $\begin{array}{c}\text { Variabel } \\
\text { Independen }\end{array}$ & $\begin{array}{c}\text { T- } \\
\text { Statistic }\end{array}$ & T-tabel & $\begin{array}{c}\text { Probab } \\
\text { ilitas }\end{array}$ & Keterangan & Hipotesis \\
\hline $\begin{array}{l}\text { Dana } \\
\text { Syirkah } \\
\begin{array}{l}\text { Temporer } \\
(\mathrm{X})\end{array}\end{array}$ & 3.056630 & 1.70814 & 0.0051 & Signifikan & Diterima \\
\hline
\end{tabular}

Sumber: Hasil Olah Data, 2019

Berdasarkan hasil uji $\mathrm{t}$ di atas, maka diperoleh hasil dari variabel Dana Syirkah Temporer (X) memiliki nilai t-Statistik sebesar 3.056630 dan t-tabel sebesar 1.70814. t-statistic > t-tabel yaitu $3.056630>1.70814$ dengan tingkat probabilitas sebesar 0.0051 , yang berarti berada dibawah 0.05. maka Ha diterima H0 ditolak. Maka variabel Dana Syirkah Temporer (X) memiliki pengaruh signifikan secara parsial terhadap variabel Bagi Hasil atas Dana Syirkah Temporer (Y) pada PT. Bank BRISyariah.

\section{PENUTUP \\ Kesimpulan}

1. Berdasarkan hasil pengujian hipotesis secara parsial (uji t) dapat disimpulkan bahwa Variabel Dana Syirkah Temporer (X) memiliki nilai t-Statistik sebesar 3.056630 dan t-tabel sebesar 1.70814. t-statistic > t-tabel yaitu 3.056630 $>1.70814$ dengan tingkat probabilitas sebesar 0.0051, yang berarti berada dibawah 0.05. maka $\mathrm{Ha}$ diterima $\mathrm{H} 0$ ditolak. Maka variabel Dana Syirkah Temporer (X) memiliki pengaruh signifikan secara parsial terhadap variabel Bagi Hasil atas Dana Syirkah Temporer (Y) pada PT. Bank BRISyariah.

2. Koefisien korelasi (r) sebesar 0.5141 atau $51.41 \%$ yang artinya bahwa variabel bebas (independent variable) faktor Dana Syirkah Temporer mempunyai hubungan yang erat dengan variabel terikat dalam hal ini adalahbagi hasil atas Dana Syirkah Temporer.

3. Koefisien determinasi (R2) sebesar 0.2643 atau $26.43 \%$ ini mencerminkan bahwa variabel terikat dapat dijelaskan oleh variabel bebas atau dengan kata lain bahwa kemampuan variabel bebas yang dijelaskan oleh variabel terikat yaitu sebesar $26.43 \%$. sedangkan sisanya sebesar 0.7357 atau $73.57 \%$ di pengaruhi oleh faktor lain yang tidak di teliti dalam penelitian ini.

\section{Saran-saran}

Berdasarkan penelitian yang penulis lakukan terdapat beberapa saran yang penulis simpulkan antara lain sebagai berikut:

1. Bagi para nasabah yang ingin menabung pada perbankan syariah khususnya PT. Bank BRISyariah tidak perlu khawatir karena produk-produk yang ditawarkan oleh bank syariah bukan hanya terletak pada dana syirkah temporer saja, akan tetapi masih banyak produk-produk lainnya.

2. Bagi Perbankan Syariah, produk-produk yang berpengaruh secara signifikan 
terhadap dana syirkah temporer perbankan syariah akan memberikan dampak yang positif.

3. Diharapkan kedepannya ada kajian lebih lanjut yang dianalisa lebih mendalam, khususnya pada perbankanperbankan lain yang tidak termasuk dalam penelitian ini.

\section{KEPUSTAKAAN}

1. Aisyah, E. N. (2015). Statistik Inferensial Parametik. Malang: Universitas Negeri Malang.

2. Antonio, M. S. (2003a). Bank Syariah dari Teori ke Praktek. Jakarta: Gema Insani Tazkia Cendekia.

3. Antonio, M. S. (2003b). Bank Syariah Dari Teori ke Praktek. Jakarta: Gema insani Tazkia Cendekia.

4. Antonio, S. M. (2001). Bank Syariah dari Teori ke Praktek. Jakarta: Gema insani.

5. Ascarya. (2008). Akad dan Produk Bank Syariah. Jakarta: PT Raja Grafindo Persada.

6. Karim, A. A. (2006). Bank Islam Analisis Fiqih dan Keuangan. Jakarta: PT. Raja Grafindo Persada.

7. Kasmir. (2002). Bank dan Lembaga Keuangan Lainnya (Keempat). Jakarta: PT Raja Grafindo Persada.

8. Lukman, A. (2014). Pengaruh ROA, DER Terhadap Kinerja Bank Syariah. Semarang: Tesis Universitas Padajajaran.

9. Muhammad. (2008). Sistem dan Prosedur Operasional Bank Syariah. Yogyakarta: UII Press Yogyakarta (Anggota IKAPI).

10. Shajdeiny, S. R. (2007). Perbankan Islam (Ketiga). Jakarta: PT. Pustaka Utama Grafiti.

11. Wardiah, M. L. (2013). Dasar-dasar Perbankan (Cetakan Pe). Bandung: Pustaka Setia.

12. Winarno, W. wahyu. (2007). Analisis
Ekonometrika dan Statistika dengan Eviews. yogyakarta: sekolah Tinggi Ilmu Manajemen YKPN. 